\title{
ANALISIS KOMPARASI KUALITAS PRODUK KAMPAS REM CAKRAM ANTARA ORIGINAL DENGAN AFTER MARKET
}

\section{Comparative Analysis of Product Quality Between Original and After Market Brake Disc Pad}

\author{
Nafsan Upara ${ }^{1 *}$, Taufik Bayu Laksono ${ }^{1}$
}

${ }^{1}$ Jurusan Teknik Mesin, Fakultas Teknik, Srengsesng Sawah Jagakarsa, Jakarta, Indonesia

Informasi artikel

Diterima: 23/02/2019 Direvisi : 27/02/2019 Disetujui: 27/02/2019

\begin{abstract}
Abstrak
Penelitian ini membahas analisis perbandingan kualitas produk kampas rem jenis cakram (disc brake) antara original dengan aftermarket . Analisis dilakukan pada hasil uji tribologi (uji friksi dan keausan), uji kekerasan, komposisi kimia dan struktur mikro untuk mengetahui ketahanan gesekan dan aus serta bahan yang digunakan. Dari hasil uji diperoleh perbandingan kualitas kampas rem original dan aftermarket yang lebih baik adalah original dimana nilai koefisien friksi 0,14 dibanding 0,11, sedangkan keausan (kondisi normal) $1.35 \mathrm{x}$ $10^{-7} \mathrm{~g} / \mathrm{mm}^{2}$.detik dan $1.22 \times 10^{-6} \mathrm{~g} / \mathrm{mm} 2$.detik. Dari uji kekerasan diperoleh kampas rem original kekerasan rata-rata $65.567 \mathrm{HVN}$ dan untuk aftermarket adalah $13.983 \mathrm{HVN}$, untuk hasil uji komposisi kimia dan struktur mikro menunjukan bahwa material kampas rem original menggunakan serat penguat berbahan karbon (C), tembaga (Cu), Besi (Fe) dan Alumunium (Al). Sedangkan bahan serat penguat yang terdapat pada kampas rem aftermarket adalah asbes, karbon (C), alumunium (Al) dan besi ( $\mathrm{Fe}$ ).
\end{abstract}

Kata Kunci: kampas rem cakram, uji tribilogi, uji kekerasaan, uji komposisi kimia, struktur mikro

\begin{abstract}
The current research addresses the comparative analysis of product quality between original and aftermarket brake disc pads. Analysis was carried out on the results of tribology tests (friction and wear tests), hardness test, chemical composition and microstructure to determine friction and wear resistance and the materials used. From the test results obtained a comparison of the quality of original and aftermarket brake pad was better is the original, value is a friction coefficient of 0.14 compared to 0.11 , while wear is $1.35 \times 10^{-7} \mathrm{~g} / \mathrm{mm}^{2} \mathrm{~s}$ and $1.22 \times 10^{-6} \mathrm{~g} / \mathrm{mm}^{2} \mathrm{~s}$ at normal conditions. From the hardness test the original brake pad obtained an average hardness of 65,567 HVN and for the aftermarket was 13,983 HVN, for the results of testing the chemical composition and microstructure showed that the original brake pad material used reinforcing fibers made from carbon (C), copper (Cu), Iron (Fe) and Aluminum (Al). While reinforcing fiber materials found in aftermarket brake pad are asbestos, carbon (C), aluminum ( $\mathrm{Al}$ ) and iron $(\mathrm{Fe})$.
\end{abstract}

Keywords: disc brake pad, tribology test, hardness test, chemical composition check, micro structure.

*Penulis Korespondensi: +62 811440927

email : nafsan@univpancasila.ac.id 


\section{PENDAHULUAN}

Rem merupakan piranti keselamatan yang berfungsi untuk memperlambat atau menghentikan laju pada kendaraan bermotor yang dikatagori sebagai komponen kritis bagi kendaraan bermotor sehingga dikenai persyaratan aturan yang ketat (Breuer et al. 2008). Terdapat dua tipe rem pada kendaraan bermotor yakni rem tipe tromol dan rem tipe cakram. Saat ini hampir seluruh kendaraan bermotor keluaran terbaru khususnya sepeda motor sudah menggunakan rem cakram pada bagian roda depannya. Kelebihan rem cakram dibandingkan dengan rem tromol adalah daya pengeremannya yang lebih maksimal.

Kampas rem dianggap sebagai salah satu komponen dasar dalam sistem rem kendaraan bermotor ditempatkan pada rem cakram, terdiri dari pelat baja dengan bahan gesekan yang diikat ke permukaan yang menghadap ke cakram rem (Aigbodion, et al. 2010).

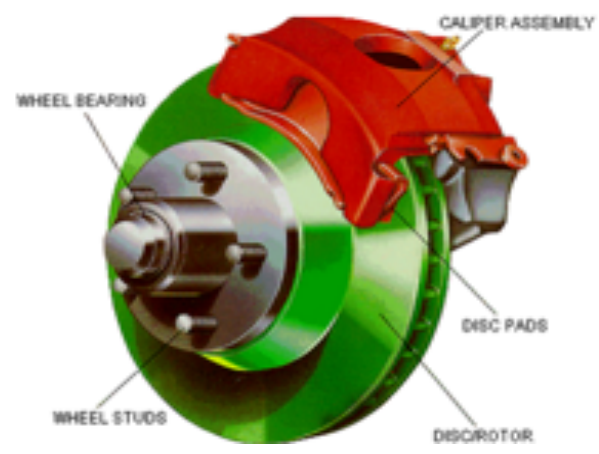

Gambar 1. Kampas pada rem cakram (Aigbodin, et al. 2010)

Kampas rem memiliki peranan yang sangat penting sebagai pencengkeram piringan cakram agar laju kendaraan dapat dikurangi atau berhenti. Gesekan yang terjadi antara kampas dengan piringan cakram saat proses pengereman mengharuskan kampas rem memiliki kualitas yang baik agar daya pengeremannya optimal dan umur pemakaiannya tahan lama. Komposisi kampas rem telah berubah dengan cepat, sebagai akibat dari larangan penggunaan asbes berdasarkan peraturan menteri Tenaga Kerja Republik indonesia No. Per.03/Men/Tahun 1985. Kampas rem hasil produksi industri biasanya mengandung sejumlah besar konstituen yang berbeda, dan masing-masing konstituen memainkan peran penting dalam kinerja pengereman (Keskin et al. 2011). Menurut Anderson (Anderson 1992), persyaratan untuk desain material gesekan meliputi gaya gesekan yang stabil, kekuatan yang andal dan ketahanan aus yang baik pada berbagai kondisi pengereman. Selain itu, bahan gesekan harus kompatibel dengan rem cakram komposit saat membentuk film gesekan yang dapat diandalkan (lapisan yang stabil) pada permukaan gesekan (Osterle, 2009; Wirth, 1994). Semua persyaratan tersebut harus dicapai dengan biaya dan beban lingkungan minimum. Beberapa penelitian telah menyelidiki komposisi baru untuk meningkatkan kinerja tribologi kampas rem (Liew, 2013; Maleque, 2012; Singh,2015). Konstituen kampas rem sering mengandung aditif gesekan, pengisi, serat pengikat dan penguat (Chan et al. 2004). Setiap konstituen memainkan peran penting dalam kinerja kampas rem yaitu :

a. Aditif gesekan menentukan sifat gesekan kampas rem, yang merupakan campuran dari abrasive dan pelumas.

b. Pengisi mengurangi biaya keseluruhan dan meningkatkan manufakturabilitas kampas rem rem.

c. Resin pengikat menyatukan komponenkomponen kampas rem.

d. Serat penguat memberikan kekuatan mekanis (mis. Logam, keramik, kaca, akrilik, dan lain lain.). Biasanya, bahan gesekan komersial terdiri dari $5-25 \%$ vol dari bahan serat.

Sebagian besar produsen tidak mengungkapkan komposisi kampas rem, komposisi kampas rem hanya dapat ditemukan dalam makalah penelitian dan kantor paten. Chan (Chan et al. 2004) menemukan bahwa persentase subkomponen dalam komposisi kampas rem dapat bervariasi secara dramatis dari satu produk ke produk lainnya. Selanjutnya, setiap subkomponen mengandung bahan dan komponen yang berbeda. Dari penelitian Nagesh (Nagesh et al. 2014), menyatakan bahwa koefisien gesek yang konstan pada berbagai kondisi operasi dapat dicapai dengan mengubah jenis dan persentase berat bahan dalam formulasi.

Tergantung pada operasi kendaraan bermotor pada kondisi medan atau jalan serta jenis bahan kampas, akan mengalami kerusakan, kampas rem harus diganti. Pemilik kendaraan bermotor memiliki opsi untuk mengganti kampas Original Equipment Manufacturer (OEM) atau after-market (pengganti atau aftermarket). Dengan adanya beragamnya produk kampas rem yang beredar di masyarakat baik yang original 
(OEM) hingga produk after market (pengganti) mengharuskan pengguna kendaraan bermotor jeli dalam memilih produk kampas rem berkualitas yang akan digunakan. Kualitas suatu produk dapat diketahui dari sifat mekanik dan komposisi dari material yang digunakan pada produk tersebut. Beberapa sifat mekanik yang perlu diperhatikan pada suatu produk kampas rem diantaranya adalah kekuatan, kekerasan, ketangguhan, keausan dan beberapa sifat mekanik lainnya (Anderson,1992). Sifat mekanik dan komposisi dari suatu produk kampas rem dapat diketahui dengan melakukan pengujian pada produk tersebut di laboratorium.

Meskipun komposisi kampas rem telah dibahas, ada sedikit diskusi tentang hubungan komposisi dengan sifat mekanik merupakan ukuran kualitas kampas rem. Namun belum ada informasi mengenai kualitas kampas rem antara produk original dan after market, sehingga tujuan dari penelitian ini adalah untuk menentukan perbandingan kualitas kampas rem cakram antara original dan aftermarket digunakan pada sepeda motor honda yang ada di Indonesia.

\section{METODOLOGI}

Kampas rem yang akan diteliti adalah kampas rem cakram yang digunakan untuk sepeda motor honda skutik didapati dari dealer resmi untuk kampas original dan toko menjual suku cadang untuk after market di Jakarta. Alir penelitian diperlihatkan pada gambar 2. Persiapan bahan kampas rem original dan after market untuk dibuat spesimen uji sebagaimana diperlihatkan pada gambar 3.
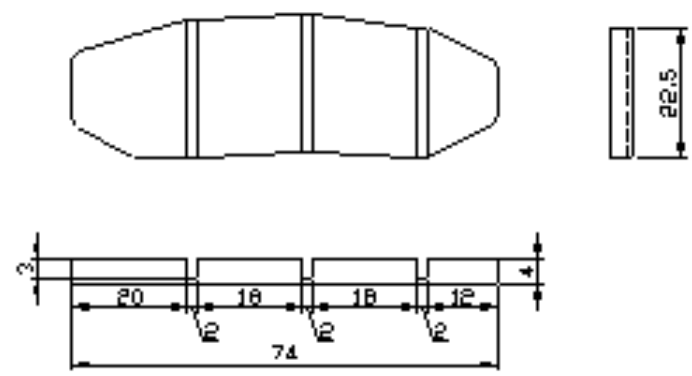

Gambar 3 Spesimen uji kampas rem

Pengujian tribologi yaitu uji keausan dan friksi dilakukan terhadap spesimen uji dengan tiga kondisi yakni pengujian dengan kondisi normal, pengujian dengan kondisi kampas rem di rendam terlebih dahulu di dalam air selama 7 hari dan pengujian dengan kondisi kampas rem di rendam terlebih dahulu di dalam minyak rem selama 2 hari.

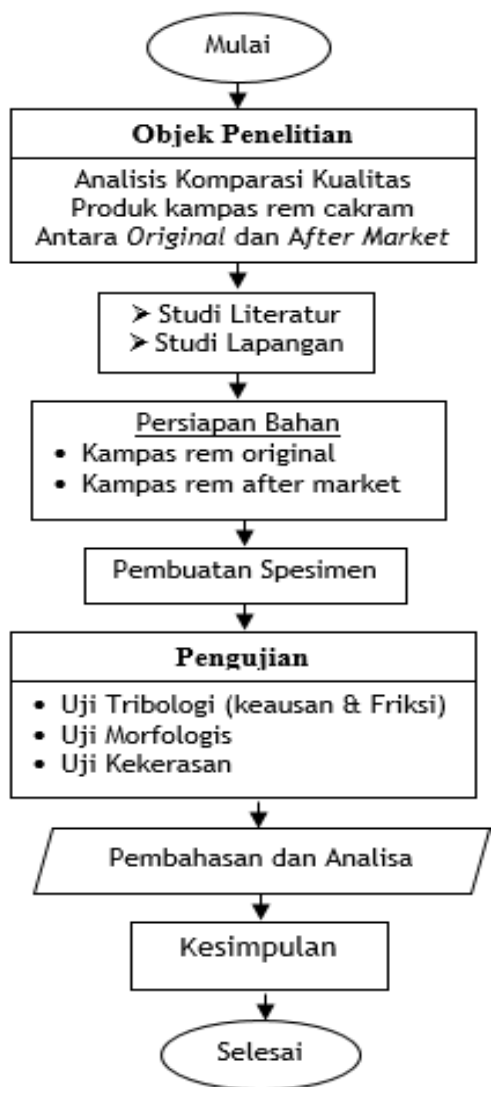

Gambar 2 Diagram alir penelitian

Tiap spesimen dilakukan di empat titik permukaan kampas rem. Masing-masing dari keempat titik tersebut dilakukan pengujian selama 5 menit.

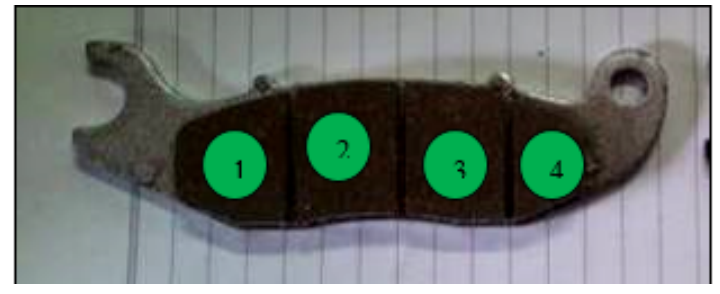

Gambar 4 Titik pengukuran tribologi

Laju keausan dihitung dengan rumus (lan, et al, 2017):

$$
W=\frac{W_{o}-W_{i}}{A \cdot t}
$$

Dimana:

$W$ : Laju keausan $\left(\mathrm{g} / \mathrm{mm}^{2}\right.$.detik)

$W_{0}$ : Berat awal spesimen sebelum aus (g)

$W_{i}$ : Berat akhir spesimen setelah aus (g)

A : Luas bidang kontak aus $\left(\mathrm{mm}^{2}\right)$ 
Uji friksi untuk mengetahui koefisien gesekan/friksi dapat dihitung dengan rumus (lan, et al, 2017):

$$
\mu=\frac{m}{2 F} \frac{V}{X}
$$

Dimana :

$\mu$ : Koefisien friksi

$\mathrm{m}$ : Massa pada roda $(\mathrm{kg})$

$\mathrm{V}$ : Kecepatan kendaran $(\mathrm{km} / \mathrm{jam})$

$\mathrm{F}$ : Gaya tekan pada kampas rem $(\mathrm{N})$

$X$ :Jarak luncur atau jarak saat pengereman sampai berhenti $(\mathrm{m})$

Untuk mengetahui kampas rem tahan terhadap deformasi plastik dilakukan uji kekerasan,uji kekerasan disini menggunakan metode vickers.

Uji mortofologis untuk mengetahui melihat struktur terkecil dan komposisi kimia. Pengamatan struktur mikro memberikan informasi tentang bentuk struktur, ukuran butir dan perbedaan komposisi suatu bahan serta serta penguat. Alat yang digunakan pada pengujian ini adalah menggunakan SEM.

Semua pengujian dilakukan pada Laboratorium Teknik Mesin Universitas Pancasila. Adapun kriteria persyaratan tekni dari kampas rem sesuai standar SAE J661 (SAE, 1997) adalah sebagai berikut :

1. Untuk nilai kekerasan sesuai standar keamanan 68 - 105 (Rockwell R)

2. Ketahanan panas $360^{\circ} \mathrm{C}$, untuk pemakaian terus menerus sampai dengan $250^{\circ} \mathrm{C}$.

3. Nilai keausan kampas rem adalah $5 \times 10-4$ - $5 \times 10-3 \mathrm{~mm}^{2} / \mathrm{kg}$ (kondisi Normal)

4. Koefisien gesek $0.14-0.27$

5. Massa jenis kampas rem adalah 1.5 $2.4 \mathrm{~g} / \mathrm{cm}^{3}$

6. Konduktifitas thermal $0.12-0.8$ W.moK

7. Tekanan spesifiknya adalah $0.17-0.98$ $\mathrm{J} / \mathrm{g}^{\circ} \mathrm{C}$

8. Kekuatan geser $1300-3500 \mathrm{~N} / \mathrm{cm}^{2}$

9. Kekuatan perpatahan $480-1500 \mathrm{~N} / \mathrm{cm}^{2}$

\section{HASIL DAN PEMBAHASAN}

\section{Uji Tribologi}

Data uji keausan kampas rem untuk keadaan kering (Normal), kondisi terendam air, dan terendam minyak diperlihatkan pada tabel 1 sampai dengan tabel 3 .

Tabel 1 Hasil Uji Keausan Kondisi Normal

\begin{tabular}{|l|c|c|c|c|c|}
\hline $\begin{array}{c}\text { Tipe } \\
\text { Spesimen }\end{array}$ & $\begin{array}{c}\mathrm{W}_{\mathrm{o}} \\
\mathbf{( g )}\end{array}$ & $\begin{array}{c}\mathrm{W}_{\mathbf{i}} \\
\mathbf{( g )}\end{array}$ & $\begin{array}{c}\mathbf{r} \\
(\mathbf{m m})\end{array}$ & $\begin{array}{c}\mathbf{A} \\
\left(\mathbf{m m}^{2}\right)\end{array}$ & $\begin{array}{c}\mathbf{t} \\
(\mathbf{d e t i k})\end{array}$ \\
\hline Original & 80.47 & 80.46 & 3.5 & 38.465 & 1920 \\
\hline Pengganti (Aftermarket) & 65.37 & 65.28 & 3.5 & 38.465 & 1920 \\
\hline
\end{tabular}

Tabel 2 Hasil Uji Keausan Kondisi Terendam Air

\begin{tabular}{|l|c|c|c|c|c|}
\hline $\begin{array}{c}\text { Tipe } \\
\text { Spesimen }\end{array}$ & $\begin{array}{c}\text { W0 } \\
\mathbf{( g )}\end{array}$ & $\begin{array}{c}\text { W1 } \\
\mathbf{( g )}\end{array}$ & $\begin{array}{c}\mathbf{r} \\
(\mathbf{m m})\end{array}$ & $\begin{array}{c}\mathbf{A} \\
\left(\mathbf{m m}^{2}\right)\end{array}$ & $\begin{array}{c}\text { T } \\
(\text { detik) }\end{array}$ \\
\hline Original & 82.39 & 82.36 & 3.5 & 38.465 & 1920 \\
\hline Pengganti (Aftermarket) & 65.82 & 65.74 & 3.5 & 38.465 & 1920 \\
\hline
\end{tabular}

Tabel 3 Hasil Uji Keausan Kondisi Terendam Minyak

\begin{tabular}{|c|c|c|c|c|c|}
\hline $\begin{array}{c}\text { Tipe } \\
\text { Spesimen }\end{array}$ & $\begin{array}{l}\text { W0 } \\
\text { (g) }\end{array}$ & $\begin{array}{l}\text { W1 } \\
\text { (g) }\end{array}$ & $\begin{array}{c}r \\
(\mathrm{~mm})\end{array}$ & $\begin{array}{c}\mathrm{A} \\
\left(\mathrm{mm}^{2}\right)\end{array}$ & $\begin{array}{c}\mathrm{t} \\
\text { (detik) }\end{array}$ \\
\hline Original & 73.62 & 73.57 & 3.5 & 38.465 & 1920 \\
\hline Pengganti (Aftermarket) & 59.01 & 58.90 & 3.5 & 38.465 & 1920 \\
\hline
\end{tabular}

Dari hasil uji tribologi dilakukan perhitungan laju keausan (W) untuk tiap spesimen :

1) Laju Keausan

a. Kampas rem original kondisi normal

$$
\begin{array}{ll}
\mathrm{W}_{\mathrm{O}} & =80.47 \mathrm{~g} \\
\mathrm{~W}_{\mathrm{I}} & =80.46 \mathrm{~g} \\
\mathrm{~A} & =38.465 \mathrm{~mm}^{2} \\
\mathrm{t} & =1920 \text { detik } \\
\mathrm{W}=(80,47-80,46) / 38,465 \times 1920 \\
\mathrm{~W}=1.35 \times 10^{-7} \mathrm{~g} / \mathrm{mm}^{2} . \text { detik } \\
\text { Atau } \mathrm{W}=3,846 \times 10^{-3} \mathrm{~mm}^{2} / \mathrm{kg} .
\end{array}
$$

b. Kampas rem aftermarket kondisi normal

$$
\begin{aligned}
& \mathrm{W}_{\mathrm{O}} \quad=65.37 \mathrm{~g} \\
& \mathrm{~W}_{\mathrm{I}} \quad=65.28 \mathrm{~g} \\
& \mathrm{~A} \quad=38.465 \mathrm{~mm}^{2} \\
& \mathrm{t} \quad=1920 \text { detik } \\
& \mathrm{W}=(65.37-65.28) / 38,465 \times 1920 \\
& \mathrm{~W}=1.22 \times 10^{-6} \mathrm{~g} / \mathrm{mm}^{2} \text {.detik } \\
& =0,4273 \mathrm{~mm}^{2} / \mathrm{kg}
\end{aligned}
$$

Dari hasil perhitungan laju keausan terlihat bahwa laju keausan kampas aftermarket lebih besar ( $1.22 \times 10^{-6}$ $\mathrm{g} / \mathrm{mm}^{2}$.detik $=0,42740,4273 \mathrm{~mm}^{2} / \mathrm{kg}$ ) dibandingkan kampas rem original $(1.35$ $\mathrm{x} 10-7 \mathrm{~g} / \mathrm{mm}^{2}$. detik $=3,846 \times 10^{-3} \mathrm{~mm}^{2} / \mathrm{kg}$ ), artinya bahwa kampas rem aftermarket keausan lebih besar dari original. Artinya kampas rem original keausan gesek lebih kecil dari kampas rem pengganti (aftermarket) dan memenuhi standar SAE J661.

c. Kampas rem original kondisi terendam air 


$$
\begin{array}{ll}
\text { Wo } & =82.39 \mathrm{~g} \\
\mathrm{Wi} & =82.36 \mathrm{~g} \\
\mathrm{~A} & =38.465 \mathrm{~mm}^{2} \\
\mathrm{t} & =1920 \text { detik }
\end{array}
$$$$
\mathrm{W}=(82.39-82.36) / 38,465 \times 1920
$$$$
\mathrm{W}=4.06 \times 10^{-7} \mathrm{~g} / \mathrm{mm}^{2} \text {.detik }
$$

d. Kampas rem aftermarket kondisi terendam air

$$
\begin{array}{ll}
\mathrm{Wo} & =65.82 \mathrm{~g} \\
\mathrm{Wi} & =65.74 \mathrm{~g} \\
\mathrm{~A} & =38.465 \mathrm{~mm} 2 \\
\mathrm{t} & =1920 \text { detik } \\
\mathrm{W}=(65.82-65.74) / 38,465 \times 1920 \\
\mathrm{~W}=1.08 \times 10^{-6} \mathrm{~g} / \mathrm{mm} 2 . \text { detik }
\end{array}
$$

Dari hasil perhitungan laju keausan terlihat bahwa laju keausan kampas aftermarket lebih besar ( $1.08 \times 10^{-6}$ $\mathrm{g} / \mathrm{mm}^{2}$.detik) dibandingkan kampas rem original $\left(4.06 \times 10^{-7} \mathrm{~g} / \mathrm{mm}^{2}\right.$.detik), artinya bahwa kampas rem aftermarket keausan lebih besar dari original untuk kondisi kampas rem cakram dilakukan perendaman di dalam air.

e. Kampas rem original kondisi terendam minyak

$$
\begin{array}{ll}
\text { Wo } & =73.62 \mathrm{~g} \\
\mathrm{Wi} & =73.57 \mathrm{~g} \\
\mathrm{~A} & =38.465 \mathrm{~mm}^{2} \\
\mathrm{t} & =1920 \text { detik } \\
\mathrm{W}=(73.62-73.57) / 38,465 \times 1920 \\
\mathrm{~W}=6.77 \times 10^{-7} \mathrm{~g} / \mathrm{mm}^{2} \text {.detik }
\end{array}
$$

f. Kampas rem aftermarket kondisi terendam minyak

$$
\begin{array}{ll}
\text { Wo } & =59.01 \mathrm{~g} \\
\mathrm{Wi} & =58.90 \mathrm{~g} \\
\mathrm{~A} & =38.465 \mathrm{~mm}^{2} \\
\mathrm{t} & =1920 \text { detik } \\
\mathrm{W}=(59,01-58.90) / 38,465 \times 1920 \\
\mathrm{~W}=1.49 \times 10^{-6} \mathrm{~g} / \mathrm{mm}^{2} \text {.detik }
\end{array}
$$

Dari hasil perhitungan laju keausan terlihat bahwa laju keausan kampas rem aftermarket lebih besar ( $1.49 \times 10^{-6}$ $\mathrm{g} / \mathrm{mm}^{2}$.detik) dibandingkan kampas rem original $\left(6.77 \times 10^{-7} \mathrm{~g} / \mathrm{mm}^{2}\right.$.detik), artinya bahwa kampas rem after market keausan lebih besar dari original untuk kondisi kampas rem dilakukan perendaman di dalam minyak rem.

\section{2) Uji Friksi}

Tabel 4 memperlihatkan hasil uji friksi yang dilakukan untuk kedua produk uji original dan after market.
Tabel 4 Hasil Uji Friksi

\begin{tabular}{|l|c|c|c|c|}
\hline \multicolumn{1}{|c|}{$\begin{array}{c}\text { Tipe } \\
\text { Spesimen }\end{array}$} & $\begin{array}{c}\text { m } \\
\mathbf{( k g )}\end{array}$ & $\begin{array}{c}\text { V } \\
\text { (km/jam) }\end{array}$ & $\begin{array}{c}\text { F } \\
(\mathbf{N})\end{array}$ & $\begin{array}{c}\text { X } \\
(\mathbf{m})\end{array}$ \\
\hline Original & 2.4 & 40 & 14.715 & 23.2 \\
\hline $\begin{array}{l}\text { Pengganti } \\
\text { (after } \\
\text { market) }\end{array}$ & 2.4 & 40 & 14.715 & 28.6 \\
\hline
\end{tabular}

Dari hasil uji friksi, dapat dihitung koefisien friksi untuk tiap spesimen berdasar rumus (2) diperoleh:

a. Kampas rem original

$$
\begin{array}{ll}
\mathrm{m} & =2.4 \mathrm{~kg} \\
\mathrm{~V} & =40 \mathrm{~km} / \mathrm{jam} \\
\mathrm{F} & =14.715 \mathrm{~N} \\
\mathrm{X} & =23.2 \mathrm{~m} \\
\mu & =\frac{2,4 \times 40}{2 x 14,715 \times 23,2} \\
\mu=0.14
\end{array}
$$

b. Kampas rem after market

$$
\begin{aligned}
\mathrm{m} & =2.4 \mathrm{~kg} \\
\mathrm{~V} & =40 \mathrm{~km} / \mathrm{jam} \\
\mathrm{F} & =14.715 \mathrm{~N} \\
\mathrm{X} & =28.6 \mathrm{~m} \\
\mu & =\frac{2,4 x 40}{2 \times 14,715 \times 28,6} \\
\mu & =0.11
\end{aligned}
$$

Dari hasil perhitungan uji koefisien friksi disimpulkan bahwa koefisien friksi kampas rem original lebih baik yakni 0.14 dibanding dengan kampas rem cakram aftermarket yakni 0.11 dan memenuhi standar SEA J661 yaitu $0.14-0.27$.

\section{Uji Kekerasan}

Tabel 5 memperlihatkan hasil uji kekerasan dari spesimen produk original dan after market.

Tabel 5 Hasil Uji Kekerasan

\begin{tabular}{|c|c|c|c|c|c|c|}
\hline Tipe Spesimen & \multicolumn{5}{|c|}{ Nilai kekerasan HVN } & Rata-rata \\
\hline Original & 64.375 & 64.375 & 67.951 & $\cdot$ & $\cdot$ & 65.567 \\
\hline Pengganti (after market) & 12.258 & 12.258 & 18.311 & 12.258 & 14.832 & 13.983 \\
\hline
\end{tabular}

Dari hasil uji kekerasan yang diperlihatkan pada tabel 6. Bahwa kampas rem original lebih keras (kekerasan rata rata $65,567 \mathrm{HVN}$ atau unggul $4 \mathrm{x}$ dari after market $(13,983 \mathrm{HVN})$. 


\section{Pengamatan Struktur Mikro dan Komposisi}

Dengan menggunakan SEM diperoleh data struktur mikro dan komposisi kimia. Hasil pengamatan SEM dengan pembesaran 500x di titik/lokasi 2 diperlihatkan pada gambar 5 dan 6.

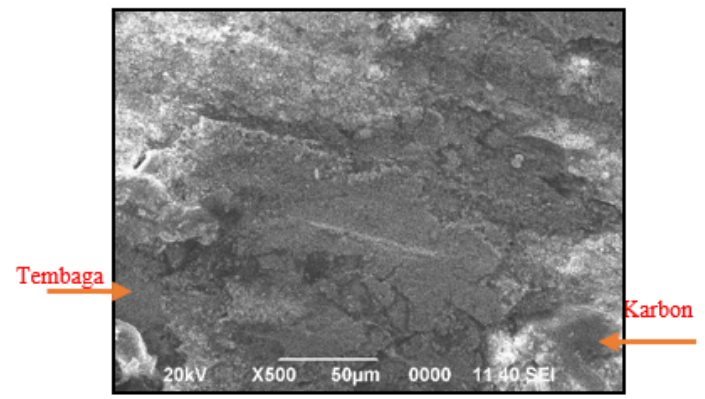

Gambar 5 Struktur mikro kampas rem original 500x (titik 2)

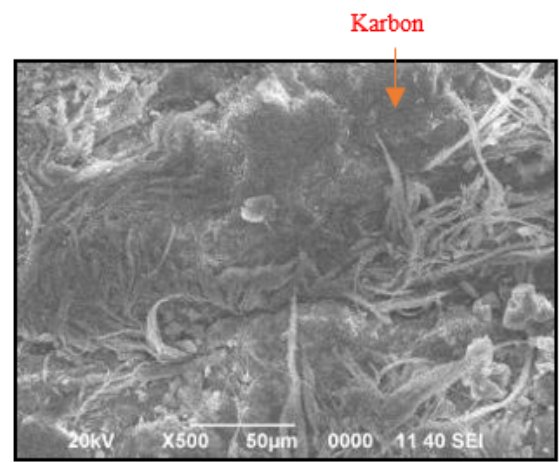

Gambar 6 Struktur mikro kampas rem after market 500x (titik 2)

Pengukuran komposisi kimia yang terdapat pada kampas rem original dan aftermarket diperlihatkan pada tabel 6 dan 7. Berdasarkan hasil pengamatan struktur mikro maka dapat diketahui unsur yang terkandung pada kampas rem. Dengan unsur ini pula dapat mengetahui karakterisitik kampas rem berdasarkan unsur pembentuknya. Dari hasil uji komposisi kimia menunjukan bahwa unsur yang paling dominan pada kampas rem original adalah karbon (C) sedangkan pada kampas rem aftermarket adalah oksigen ( 0 ). Unsur karbon yang dominan pada kampas rem original mengakibatkan kampas rem original memiliki nilai kekerasan lebih dibandingkan dengan kampas rem cakram aftermarket.

Dari hasil uji komposisi kimia juga menunjukan bahwa material kampas rem original menggunakan serat penguat berbahan karbon $(\mathrm{C})$, tembaga $(\mathrm{Cu})$, besi $(\mathrm{Fe})$ dan alumunium (Al). Sedangkan Bahan serat penguat yang terdapat pada kampas rem aftermarket adalah asbes, karbon (C), alumunium ( $\mathrm{Al}$ ) dan besi $(\mathrm{Fe})$.

Tabel 6 Unsur Kimia pada Kampas Original

\begin{tabular}{|c|c|c|}
\hline No & Unsur & Persentase Massa (\%) \\
\hline 1. & $\mathrm{C}$ & 35.52 \\
\hline 2. & $\mathrm{O}$ & 12.95 \\
\hline 3. & $\mathrm{Al}$ & 0.70 \\
\hline 4. & $\mathrm{Si}$ & 1.50 \\
\hline 5. & $\mathrm{~S}$ & 1.19 \\
\hline 6. & $\mathrm{Ti}$ & 2.28 \\
\hline 7. & $\mathrm{Fe}$ & 0.98 \\
\hline 8. & $\mathrm{Cu}$ & 28.13 \\
\hline 9. & $\mathrm{Zr}$ & 6.93 \\
\hline 10. & $\mathrm{Mo}$ & 2.45 \\
\hline 11. & $\mathrm{Ba}$ & 7.36 \\
\hline
\end{tabular}

Tabel 7 Unsur Kimia pada Kampas aftermarket

\begin{tabular}{|c|c|c|}
\hline No & Unsur & Persentase Massa (\%) \\
\hline 1. & $\mathrm{C}$ & 24.95 \\
\hline 2. & $\mathrm{O}$ & 40.28 \\
\hline 3. & $\mathrm{Mg}$ & 14.77 \\
\hline 4. & $\mathrm{Si}$ & 10.78 \\
\hline 5. & $\mathrm{~S}$ & 0.63 \\
\hline 6. & $\mathrm{Ca}$ & 3.24 \\
\hline 7. & $\mathrm{Cr}$ & 2.10 \\
\hline 8. & $\mathrm{Fe}$ & 1.94 \\
\hline 9. & $\mathrm{Ba}$ & 1.29 \\
\hline
\end{tabular}

Berdasarkan hal tersebut, dapat terlihat perbedaannya yang terletak pada serat penguatnya yakni kampas rem original menggunakan serat penguat tembaga $(\mathrm{Cu})$ sedangkan kampas rem aftermarket menggunakan serat penguat asbes. Pada kampas rem original, tembaga membuat kampas rem cakram original memiliki sifat keausan yang lebih baik dibanding kampas rem aftermarket karena unsur tembaga (Cu) memiliki sifat redaman yang baik terhadap gesekan. Sedangkan kampas rem cakram aftermarket menggunakan asbes pada serat penguatnya dimana asbes hanya bisa bertahan sampai dengan suhu 200oC selebihnya akan terjadi blong (fading) pada temperatur $250 \mathrm{oC}$, hal inilah yang membuat kampas rem aftermarket lebih cepat aus dibandingkan kampas rem original. Adanya unsur oksigen yang lebih banyak pada kampas rem aftermarket $37.26 \%$ dibanding dengan kampas rem original $14.51 \%$ juga menyebabkan sifat tahan korosi pada kampas rem aftermarket berkurang sehingga menyebabkan kampas rem aftermarket lebih cepat aus dibandingkan kampas rem original. 


\section{SIMPULAN}

Berdasarkan hasil uji kekerasan didapatkan hasil untuk kampas rem original memiliki angka kekerasan rata-rata 65.567 HVN sedangkan untuk kampas rem aftermarket memiliki angka kekerasan ratarata 13.983 HVN. Dari nilai kekerasan ini terlihat kampas rem aftermarket tidak tahan terhadap keausan.

Kampas rem original memiliki tingkat kekerasan yang lebih baik. Hal itu disebabkan karena pengaruh komposisi unsur karbon yang lebih dominan, sehingga memiliki tingkat kekerasan yang lebih.

Kampas rem aftermarket memiliki kekerasan yang kurang baik. Hal itu disebabkan karena komposisi unsur oksigen yang lebih dominan.

Hasil perhitungan hasil uji keausan didapatkan hasil untuk kampas rem original memiliki nilai keausan $1.35 \times 10^{-7}$ $\mathrm{g} / \mathrm{mm}^{2}$.detik (kondisi normal), $4.06 \times 10^{-7}$ $\mathrm{g} / \mathrm{mm}^{2}$.detik (kondisi dilakukan perendaman air) dan $6.77 \times 10^{-7} \mathrm{~g} / \mathrm{mm}^{2}$.detik (kondisi dilakukan perendaman minyak rem) sedangkan untuk kampas rem aftermarket memliki nilai keausan $1.22 \times 10^{-6}$ $\mathrm{g} / \mathrm{mm}^{2}$.detik (kondisi normal), $1.08 \times 10^{-6}$ $\mathrm{g} / \mathrm{mm}^{2}$.detik (kondisi dilakukan perendaman air) dan $1.49 \times 10^{-6} \mathrm{~g} / \mathrm{mm}^{2}$.detik (kondisi dilakukan perendaman minyak rem). Dari hasil perhitungan laju keausan terlihat bahwa laju keausan kampas aftermarket lebih besar dibandingkan kampas rem original, artinya bahwa kampas rem Peraturan Menteri Tenga Kerja Republik Indonesia No. Per.03/Men/Tahun 1985 keausan lebih besar dari original.

Dari hasil uji koefisien friksi didapatkan hasil untuk kampas rem original memiliki nilai koefisien friksi 0.14 sedangkan untuk kampas rem cakram aftermarket memiliki nilai koefisien friksi 0.11. Dari nilai koefisien friksi ini terlihat kampas rem original lebih baik nilai koefisien friksinya dan memenuhi standar SAE J661.

Dari hasil uji komposisi kimia juga menunjukan bahwa material kampas rem original menggunakan serat penguat berbahan karbon $(\mathrm{C})$, tembaga $(\mathrm{Cu})$, Besi $(\mathrm{Fe})$ dan Alumunium (Al). Sedangkan bahan serat penguat yang terdapat pada kampas rem aftermarket adalah asbes, karbon (C) alumunium (Al) dan besi (Fe), dimana berdasarkan Peraturan Menteri Tenga Kerja Republik Indonesia No. Per.03/Men/Tahun 1985, bahan asbes sudah dilarang diguanakan karena menimbulkan masalah kesehatan.

\section{DAFTAR PUSTAKA}

Aigbodion, V.S. Et al., 2010. Development of asbestos-free brake pad using bagasse, Tribology in industry, Volume 32, (1), , pp. 12-18.

A.E. Anderson,1992. Friction and Wear of Automotive Brakes, in ASM Handbook, Friction Lubrication and Wear Technology, Vol. 18. ASM International, Materials Park, OH, pp. 569-577.

Breuer.B \& Bill.K.,2008. Brake Technology Handbook. SAE International, Pennsylvania, PA.

Chan.D., Et al. 2004., Review of automotive brake friction materials, Proceeding Institution Mechanical Engineers Vol 218 Part D: J. Automobile Eng.

Ian Hutchings \& Philip Shipway.,2017. Tribology, Friction and Wear of Engineering Material, second edition Butterworth-Heinemann an imprint of Elsevier

Keskin.A,.2011. Investigation of using natural zeolite in brake pad, Scientific Research and Essays Vol. 6(23), pp. 4893-4904.

Liew. K.W., Et al,.2013., Frictional performance evaluation of newly designed brake pad materials, Materail and Design. 48, pp. 25-33.

Maleque M.A,Et al,. 2012. New natural fibre reinforced aluminium composite for automotive brake pad, International Jurnal Mechanical \& Material Engineering. 7.

Nagesh S.N., C. Siddaraju, S.V.Prakash, and M.R. Ramesh,.2014., Characterization of brake pads by variation in composition of friction materials, Procedia Mat. Sci. 5, pp. 295-302.

Osterle.W, Et al,.2009. A comprehensive microscopic study of third body formation at the interface between a brake pad and brake disc during the final stage of a pin-on-disc test, Wear 267 , pp. 781-788.

Peraturan Menteri Tenga Kerja Republik Indonesia No. Per.03/Men/Tahun 1985 Tentang Keselamatan dan Kesehatan Kerja Pemakaian Asbes 
SAE J661, 1997. Brake Lining Quality Test Procedure. Society of Automotive Engineers Internastional

Singh.T, Et all,. 2015, Assessment of braking performance of lapinus-wollasotnite fibre reinforced friction composite materials, Journal of King Saud University - Engineering Sciences, pp. 18. http://dx.doi. org/10.1016/j.jksues.

SNI 09-2663-1992, Cara Uji Ketahanan Terhadap Air, Larutan Garam, Minyak Pelumas dan Cairan Rem Untuk Kampas Rem Kendaraan Bermotor

Wirth.A, Et al,. 1994. A fundamental tribo chemical study of the third body layer formed during automotive friction braking, Wear 179, pp. 75-81. 